\title{
Intra-articular glucocorticoid injections decrease the number of steroid hormone receptor positive cells in synovial tissue of patients with persistent knee arthritis
}

\author{
Marlies C van der Goes, ${ }^{1}$ Rainer H Straub, ${ }^{2}$ Marion J G Wenting, ${ }^{1}$ Silvia Capellino, ${ }^{2}$ \\ Johannes W G Jacobs, ${ }^{1}$ Zalima N Jahangier, ${ }^{1,3}$ Luise Rauch, ${ }^{2}$ Johannes W J Bijlsma, \\ Floris P J G Lafeber ${ }^{1}$
}

${ }^{1}$ Department of Rheumatology \& Clinical Immunology, University Medical Center Utrecht, Utrecht, The Netherlands ${ }^{2}$ Laboratory of Experimental Rheumatology and Neuroendocrino-Immunology, Department of Internal Medicine I, University Hospital Regensburg, Regensburg, Germany

${ }^{3}$ Department of Rheumatology, Tergooi Hospitals, Hilversum/ Blaricum, The Netherlands

\section{Correspondence to}

Marlies van der Goes, Department of Rheumatology \& Clinical Immunology (F02.127), University Medical Center

Utrecht, P0 Box 85500, 3508 GA Utrecht, The Netherlands; m.c.vandergoes@umcutrecht.nl

Received 4 November 2011 Accepted 26 February 2012 Published Online First 13 April 2012

\section{ABSTRACT}

Objectives To explore changes in the number of steroid hormone receptor positive cells in synovial tissue (ST) after intra-articular glucocorticoid injection, to correlate these changes with changes in clinical variables, and to evaluate whether the number of steroid hormone receptor positive cells predicted the clinical response to glucocorticoid injection.

Methods Fourteen patients with persistent knee arthritis despite at least two previous injections in an outpatient setting received an intra-articular injection with glucocorticoids, followed by 3 days of admission with bed rest. Clinical efficacy was assessed at 6 and 12 weeks. ST biopsies were performed 2 weeks before and 12 weeks after the injection. The presence of different cell types (T cells, macrophages, fibroblast-like synoviocytes) and numbers of glucocorticoid, androgen and oestrogen $\alpha$ and $\beta$ receptor positive cells were evaluated by histochemistry.

Results Patients showed, despite previous failures, good clinical response to glucocorticoid injection, with significant improvement in erythrocyte sedimentation rate, visual analogue scale (VAS) for pain, and joint disability score. The number of steroid hormone receptor positive cells decreased markedly ( $p<0.05$ for all four receptors). The decrease in oestrogen receptor $\alpha$ positive cells correlated significantly with the improvement in VAS for pain and joint disability score. The number of glucocorticoid, androgen and oestrogen $\alpha$ and $\beta$ receptor positive cells before injection did not predict the effect of treatment.

Conclusions Intra-articular glucocorticoid injections followed by bed rest for persistent arthritis are clinically effective and significantly decrease the number of steroid hormone receptor positive cells in ST. The relevance of the latter needs further study.

\section{INTRODUCTION}

Steroid hormones of the adrenal and gonadal glands, such as glucocorticoids, androgens and oestrogens, are important in the neuroendocrine immune system and are involved in the immunological imbalance in several autoimmune diseases. ${ }^{1} 2$ Systemically as well as locally administered glucocorticoids clearly exhibit anti-inflammatory actions. $^{3-6}$ In rheumatoid arthritis (RA), systemic glucocorticoids are capable of slowing down the progression of joint destruction. ${ }^{7-11}$ It was recently demonstrated that the inclusion of $10 \mathrm{mg}$ prednisone from the start of therapy in a methotrexatebased tightly controlled treatment strategy resulted in fewer radiographic erosions without increasing toxicity, and decreased the need for treatment with biological agents. ${ }^{12}$ The effects of androgens on RA disease activity are limited..$^{13-15}$ The role of oestrogens in RA and autoimmune diseases is more difficult to define, ${ }^{16}$ and may be influenced by the presence of its receptors (oestrogen receptor $\alpha$ and $\beta$ (ER $\alpha$ and $E R \beta)$ ), as preponderance of one ER subtype over another may influence the effects of oestrogens. ${ }^{17}$

Previous research has shown the presence of steroid hormone receptors in different cells in the synovial tissue (ST) as well as in peripheral blood mononuclear cells of patients with RA. ${ }^{18-24}$ Steroid hormone receptors in ST are localised in inflammatory lymphoid cells and synoviocytes. ${ }^{23}$ However, the effects of intra-articular glucocorticoid injections on the presence of steroid hormone receptor positive cells have thus far not been described.

In rheumatic diseases, systemically administered glucocorticoids inhibit expression of the glucocorticoid receptor (GR) on peripheral blood mononuclear cells in a dose-dependent way. ${ }^{25}$ However, previous studies have not demonstrated a direct relation between peripheral blood mononuclear cell GR expression and efficacy of oral glucocorticoid treatment. $^{26}$ This does not exclude the possibility that there is a correlation at the local level between the expression of this and other steroid receptors in ST cells and the response to intra-articular glucocorticoid treatment. It has been shown that intra-articularly injected glucocorticoids decrease serum levels of dehydroepiandrosterone sulphate, testosterone and oestradiol. ${ }^{27}$ However, no data are available on the local effect of intra-articular glucocorticoids on expression of different steroid hormone receptors in ST.

Therefore, we performed an explorative study in which we aimed to:

1. explore whether the numbers of $G R$, androgen receptor (AR), ER $\alpha$ and $E R \beta$ positive cells in ST change after intra-articular glucocorticoid injection in persistent knee arthritis; 
2. determine whether changes in numbers of these positive cells correlate with improvement in clinical variables;

3. identify whether the number of steroid hormone receptor positive cells in ST at baseline predicts the clinical response to glucocorticoid injections.

\section{METHODS}

\section{Patients}

Fourteen patients with RA or undifferentiated arthritis (UA) and with persistent knee arthritis who gave written informed consent to have a serial ST biopsy were included at four rheumatology clinics in The Netherlands. The patient characteristics are given in table 1 . The requirement for participation was persistent knee arthritis despite at least two intra-articular glucocorticoid injections in an outpatient setting, which was ongoing for at least 4 weeks after the last glucocorticoid injection. The study protocol was approved by the ethics committee of the participating institutions and conducted according to the Declaration of Helsinki.

\section{Treatment}

Patients received intra-articular treatment with either $20 \mathrm{mg}$ triamcinolone hexacetonide $(\mathrm{n}=9)$ or $40 \mathrm{mg}$ triamcinolone acetonide (Kenacort; Bristol-Meyers Squibb BV , The Netherlands; $\mathrm{n}=5$ ), after aspiration of the synovial fluid. Availability determined the use of two different glucocorticoid preparations, and the dosage adjustment was based on pharmacokinetic reports. ${ }^{28}$ There were no significant differences between the two preparations in (change of) number of steroid hormone positive cells ( $p$ values all $>0.1$ ), and the direction of change was similar for both preparations. Therefore they were considered clinically equipotent, and results are presented for both glucocorticoids together. Treatment was followed by immobilisation of the knee with a brace and $72 \mathrm{~h}$ bed rest at the clinic, because bed rest improved outcomes in an earlier study. ${ }^{29}$

\section{Clinical assessment}

At baseline and at 6 and 12 weeks after intra-articular glucocorticoid injection, clinical assessments were performed by one investigator. Pain in the joint was scored by the patient on a visual analogue scale (VAS), ranging from 0 (no pain) to $100 \mathrm{~mm}$ (maximal pain). Functional disability of the treated joint was scored on a five-point Likert scale ( $1=$ complete immobilisation, $5=$ no symptoms). The acute phase reactants, erythrocyte sedimentation rate (ESR) and C-reactive protein (CRP), were also measured.

\section{Biopsy procedure and tissue preparation}

Two weeks before and 12 weeks after treatment, ST biopsy samples were taken using a blind procedure from the suprapatellar pouch and medial parapatellar gutter, after intra-articular anaesthesia with lidocaine. No prophylactic antibiotics were administered, and no aspiration of synovial fluid was performed at the time of biopsy. The biopsy procedures were performed by one investigator with straight arthroforce III biopsy forceps (Storz, Tuttlingen, Germany) with a diameter of $2.3 \mathrm{~mm}$, through a biopsy canule (Storz) with a diameter of $3.2 \mathrm{~mm}$ and length of $7 \mathrm{~cm}$. Ten pieces of ST were snap-frozen en block in Tissue Tek OCT (Miles, Elkhart, Indiana, USA) by immersion in methylbutane $\left(-70^{\circ} \mathrm{C}\right)$ immediately after retrieval and stored in liquid nitrogen. ${ }^{30}$

Sections $(5 \mu \mathrm{m})$ of the combined biopsy pieces were cut in a cryostat and mounted on glass slides (Star Frost adhesive slides;
Table 1 Characteristics of patients

\begin{tabular}{lccc}
\hline & All $(\mathbf{n = 1 4 )}$ & RA (n=8) & UA (n=6) \\
\hline Female/male (n) & $6: 8$ & $3: 5$ & $3: 3$ \\
Age (years) & $53 \pm 15$ & $59 \pm 13$ & $44 \pm 14$ \\
Disease duration (years) & $7(2-11)$ & $9(2-28)$ & $5(1-9)$ \\
Erosive joint disease (n) & 5 & 5 & 0 \\
Duration of knee arthritis (months) & $36 \pm 30$ & $33 \pm 24$ & $40 \pm 38$ \\
Number of injections during & $3 \pm 2$ & $3 \pm 2$ & $2 \pm 1$ \\
past year & & & \\
Generic glucocorticoid & & & \\
$\quad$ Triamcinolone hexacetonide (n) & 9 & 3 & 6 \\
$\quad$ Triamcinolone acetonide (n) & 5 & 5 & 0 \\
$\quad$ Current therapy & & & \\
$\quad$ NSAIDs (n) & 9 & 6 & 3 \\
DMARDs (n) & 9 & 8 & 1 \\
$\quad$ Oral glucocorticoids (n) & 5 & 4 & 1 \\
ESR (mm/h) & $34(11-76)$ & $73(26-88)$ & $13(7-32)$ \\
CRP (mg/l) & $16(5-95)$ & $68(10-124)$ & $7(4-12)$ \\
\hline
\end{tabular}

Data represent mean $\pm S D$, or median (IQR) when not normally distributed. A significant difference between the RA and UA group was found only for DMARD use $(p=0.008)$ and $\operatorname{ESR}(\mathrm{p}=0.017)$.

CRP, C-reactive protein; DMARD, disease-modifying antirheumatic drug; ESR, erythrocyte sedimentation rate; NSAID, non-steroidal anti-inflammatory drug; RA, rheumatoid arthritis; $U A$, undifferentiated arthritis.

Knittelgläser, Braunschweig, Germany). The slides were airdried overnight and sealed by wrapping in tin foil to store at $-70^{\circ} \mathrm{C}$ until histochemical analyses. In addition, five pieces of ST were fixed in formalin, embedded in paraffin, and cut into $5 \mu \mathrm{m}$ sections of the combined biopsy pieces for steroid hormone receptor staining.

\section{Immunohistochemistry}

Serial frozen sections were stained with the following mouse monoclonal antibodies: anti-CD3 (SK7; Becton-Dickinson, San Jose, California, USA) to detect T lymphocytes, anti-CD68 (ERM11; Dako, Glostrup, Denmark) to detect macrophages, and anti-CD55 (clone 67; Serotec, Oxford, UK) to detect fibroblast-like synoviocytes. Staining was centralised and performed according to a three-step immunoperoxidase method, as described previously, ${ }^{30}$ with the material of all patients processed at the same time.

The paraffin sections were deparaffinised in xylene and rehydrated in a descending ethanol concentration series. Procedures were followed as described previously. ${ }^{18}$ Slides were placed in citrate buffer (S2369; Dako) and heated for $40 \mathrm{~min}$ in a water bath at $90^{\circ} \mathrm{C}$. They were then washed in Tris buffer $(\mathrm{pH}$ 7.6), trypsin-digested for $20 \mathrm{~min}$ at $37^{\circ} \mathrm{C}$ (trypsin $10 \mathrm{x}$, PAA, Pasching, Austria), and washed again in Tris buffer. After that, they were incubated for $45 \mathrm{~min}$ in blocking solution consisting of $10 \%$ bovine serum albumin (Sigma, Zwijndrecht, The Netherlands), $10 \%$ fetal calf serum (PAN Biotech, Aidenbach, Germany) and 10\% goat serum (Sigma) and washed in Tris buffer. Antibodies to GR (35473; Menarini, Florence, Italy), AR (DLN-09477; Dianova, Hamburg, Germany), ER $\alpha$ (MA1-310; Dianova) and ER $\beta$ (ab288; Abcam, Cambridge, Massachusetts, USA) were applied at pretested dilutions overnight at room temperature. As a negative control, sections were incubated without the primary antibody. After a wash in Tris buffer, the secondary antibody (D0486; Dako) was applied for $1 \mathrm{~h}$ at room temperature. After a further wash in Tris, these slides were incubated with the chromogen, 5-bromo-4-chloro-3indoyl phosphate/nitroblue tetrazolium, and levamisole was added to block endogenous alkaline phosphatase (K0598 and X3021; Dako). 


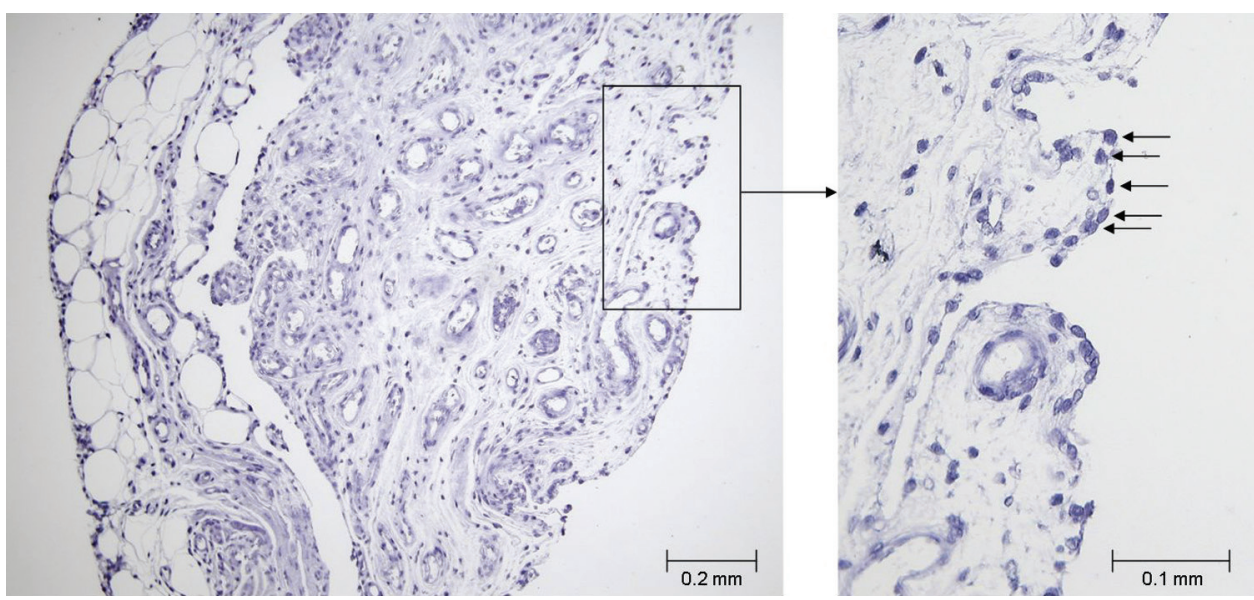

Figure 1 Synovial tissue stained for androgen receptor positive cells. These figures are examples of one of the stains used for steroid hormone receptors. An overview of the tissue is shown on the left $(100 \times)$, with a more detailed view on the right $(200 \times)$. The dark cells $($ some are indicated by arrows) are positive for androgen receptors.
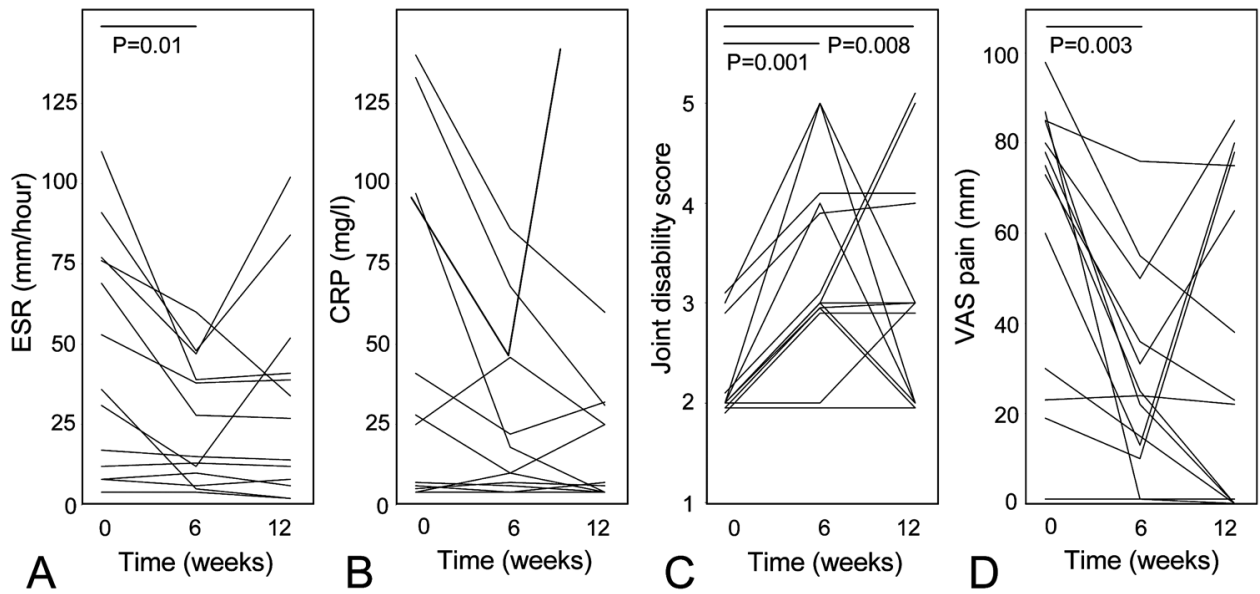

Figure 2 Clinical scores before versus 6 and 12 weeks after glucocorticoid treatment. The measurements before and 6 and 12 weeks after treatment were complete for all patients, except for two missing ESR and CRP values at 6 and 12 weeks. Joint disability scores range from 1 (complete immobilisation) to 5 (no symptoms), and thus an increase in this score reflects improvement. VAS pain scores range from 0 to $100 \mathrm{~mm}$, and thus a decrease in this score reflects improvement. Clinical scores after 6 versus 12 weeks are all not significant. CRP, C-reactive protein; ESR, erythrocyte sedimentation rate, VAS pain, visual analogue scale for pain of the treated joint.

\section{Microscopic analysis}

Sections stained for CD markers were randomly analysed by one observer blinded to the time point using digital image analysis, as previously described. ${ }^{31}$ Of the sections stained for steroid hormone receptors, representative high-power fields (200x) were examined independently by two observers (for an example, see figure 1). The observers were blinded to all clinical data and the time point. Numbers of receptor positive cells were averaged from nine selected high-power fields. The cell counts were expressed per $\mathrm{mm}^{2}$.

\section{Data analysis}

Baseline characteristics of patients with RA and UA were tested for differences with independent samples $T$ tests or Mann-Whitney $U$ tests, where appropriate, and differences in categorical data with Pearson $\chi^{2}$ tests with continuity corrections. Means of the histology scores of the two investigators were used. Since most variables were not normally distributed, non-parametric statistics was applied. For comparison of clinical variables and histological scores before and after injection, the Wilcoxon signed ranks test was used, and, for comparisons between groups, the Mann-Whitney $U$ test was applied. To analyse relations between clinical outcome, receptor expression and CD markers, Spearman's correlations were performed. Prediction was tested with linear regression analyses (with absolute values of, and change in, ESR, CRP, VAS for pain and disability scores at 6 and 12 weeks after treatment as dependent variables). For all analyses, $p$ values of $<0.05$ were considered to be significant. Because of the explorative nature of this study, Bonferroni adjustment was not applied. Analyses were performed with PASW V.18.0 (SPSS, Chicago, Illinois, USA).

\section{RESULTS}

\section{Clinical effect}

In patients with persistent knee arthritis despite previous injections, intra-articular glucocorticoid injections appeared to be effective, albeit temporarily (figure 2). A significant improvement in ESR, disability score and VAS pain score was observed at 6 weeks, which had partially faded after 12 weeks. 


\section{Effect of glucocorticoids on the presence of steroid hormone receptor positive cells}

The number of steroid hormone receptor positive cells decreased significantly after intra-articular glucocorticoid injection for all four receptors tested (figure $3 \mathrm{~A}$ ). Decreases were similar for patients with RA and UA, and independent of the use of disease-modifying antirheumatic drugs or non-steroidal antiinflammatory drugs (data not shown). Although changes in numbers of steroid hormone receptor positive cells were smaller in the group of five patients using oral glucocorticoid medication, the directions of the effects were uniform (data not shown). The decrease in steroid hormone receptor positive cells was similar in men and women, except for the decrease in ER $\alpha$ positive cells, which was more pronounced in women than men $(p=0.03)$. The inter-relationship for changes in the different steroid hormone receptors was examined, and a weak correlation was found for most of them (Spearman correlation coefficients of 0.13-0.44, not significant). For the change in the two subtypes of ERs, a strong association was found (Spearman correlation coefficient 0.72, $\mathrm{p}=0.004$; figure $3 \mathrm{~B}$ ).

\section{Steroid hormone receptors and ST inflammation}

Several markers of synovial infiltration were tested (figure 4). The number of $T$ cells (CD3 positive cells) decreased significantly $(p=0.01)$. Other cell types such as macrophages (CD68 positive cells) in the lining and sublining and fibroblast-like synoviocytes (CD55 positive cells) did not show a clear change. Changes in synovial infiltration of the different cell types did not correlate with changes in numbers of steroid hormone receptor positive cells (data not shown).

\section{Steroid hormone receptors and clinical efficacy}

Decreases in the number of GR, AR and ER $\beta$ positive cells were not associated with change in any clinical variable (ESR, CRP, VAS for pain, disability score). The decrease in number of ER $\alpha$ positive cells on the other hand correlated with an improvement in VAS for pain and joint disability at 6 weeks after glucocorticoid injection (Spearman correlation coefficient $0.65, \mathrm{p}=0.02$, and Spearman correlation coefficient $-0.59, \mathrm{p}=0.03$; figure 5 ). These correlations had disappeared at 12 weeks after treatment (data not shown), as the clinical effect also faded away.

\section{Prediction}

The number of GR, AR, ER $\alpha$ or ER $\beta$ positive cells in ST before treatment did not predict the clinical response to intra-articular glucocorticoid injections (no significant $\beta$ of receptor expression in linear regression analyses with clinical variables as dependent

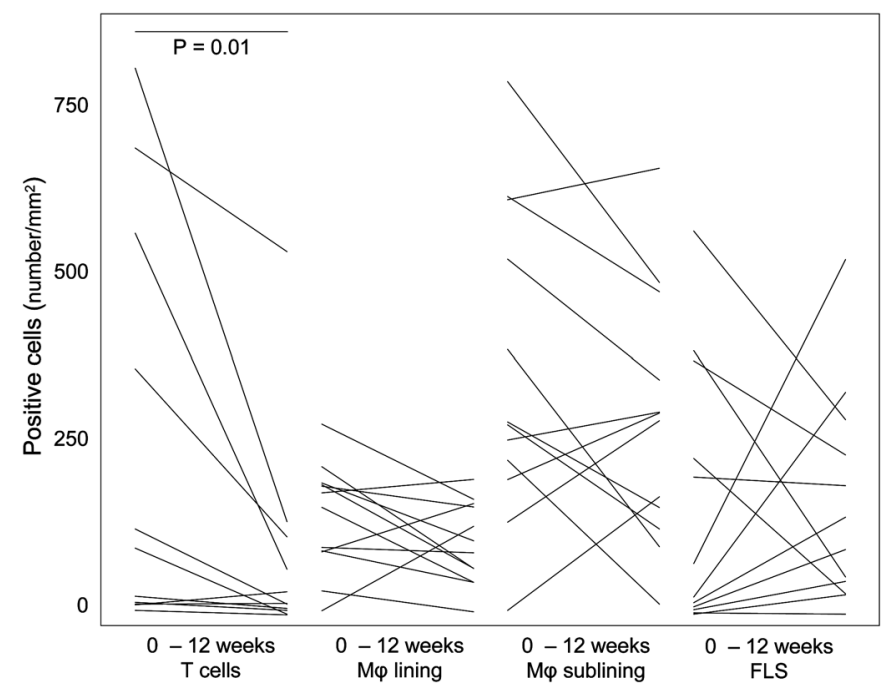

Figure 4 Presence of different cell types in the synovial tissue before and after glucocorticoid injection. Measurements of infiltration of different cell types in the synovial lining and sublining before and after intra-articular glucocorticoid injection were performed in 13 patients and are expressed as cell counts per $\mathrm{mm}^{2}$ (divided by two for the $\mathrm{M} \varphi$ scores). The number of T cells decreased significantly $(p=0.01)$. Other cell types did not change significantly. FLS, fibroblast-like synoviocytes (CD55); M $\varphi$, macrophages (CD68); T cells, T lymphocytes (CD3).
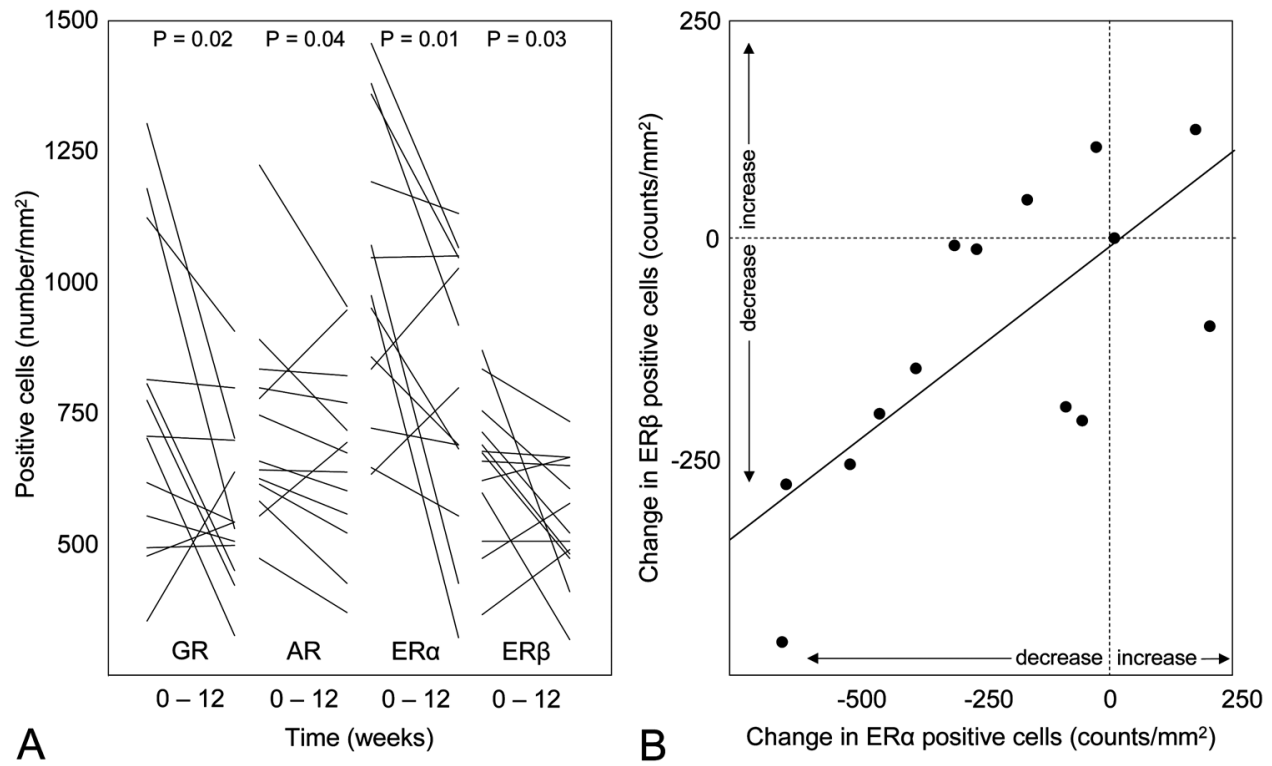

Figure 3 Number of steroid hormone receptor positive cells before and after glucocorticoid injection and coupling of change in ER $\alpha$ and ER $\beta$ positive cells. Steroid hormone receptors are expressed as the number of positive cells per $\mathrm{mm}^{2}$. The $\mathrm{p}$ values indicate significant differences between values before treatment and 12 weeks after intra-articular glucocorticoid injection (A). Strong coupling of change in number of positive cells was found for the two types of ER (Spearman correlation coefficient 0.72, $p=0.004 ; B$ ). AR, androgen receptor; ER, oestrogen receptor; GR, glucocorticoid receptor. 


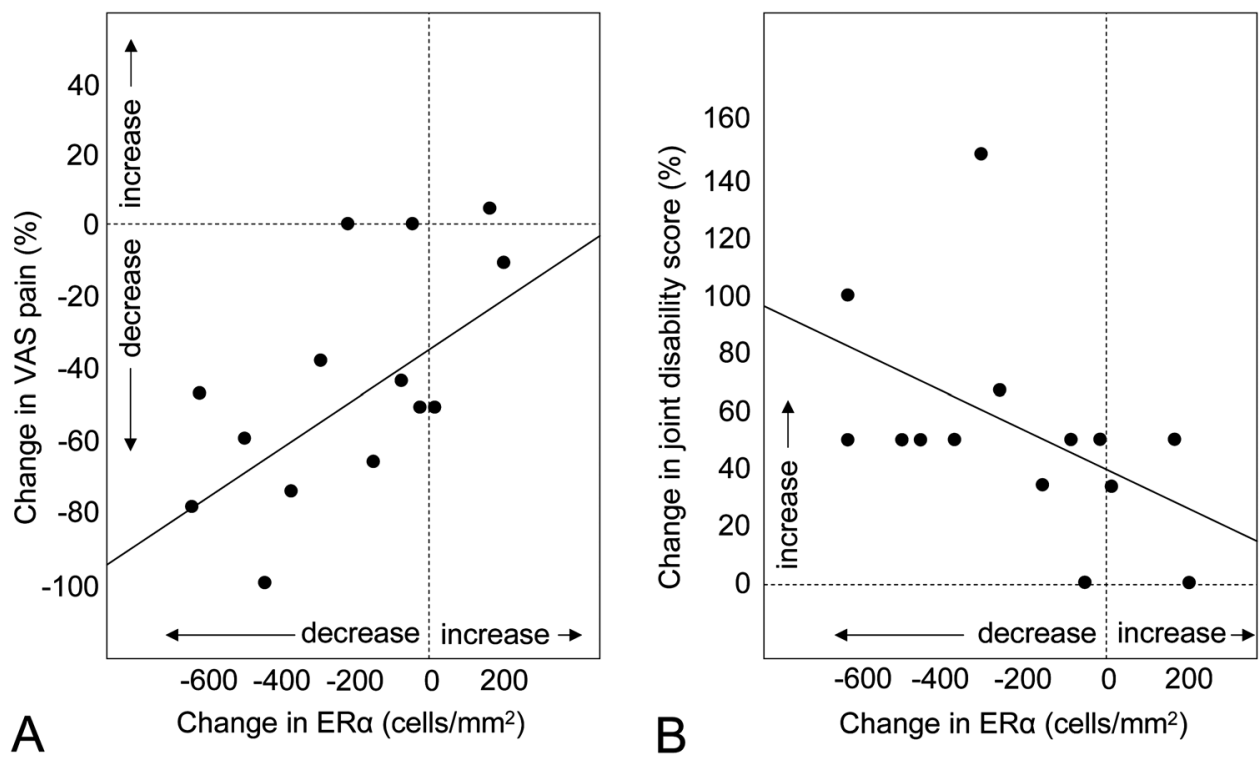

Figure 5 Correlations between change in ER $\alpha$ positive cells and clinical scores. The decrease in ER $\alpha$ positive cells ( $x$ axis) correlated with an improvement in VAS for pain and joint disability score (y axis) at 6 weeks after glucocorticoid injection. (A) Percentage change in VAS for pain and change in number of $E R \alpha$ positive cells (Spearman correlation coefficient $0.65, p=0.02$ ). The positive correlation coefficient indicates that a decrease in ER $\alpha$ positive cells correlates with a decrease in VAS for pain. (B) Percentage change in joint disability score, which correlates with the change in number of ER $\alpha$ positive cells (Spearman correlation coefficient $-0.59, p=0.03$ ). Joint disability scores ranged from 1 (complete immobilisation) to 5 (no symptoms). So, the negative correlation coefficient indicates that a decrease in ER $\alpha$ positive cells correlates with a decrease in disability. ER, oestrogen receptor; VAS, visual analogue scale.

variables). The number of $\mathrm{T}$ cells, macrophages and fibroblastlike synoviocytes at baseline also did not correlate with clinical response to this therapy.

\section{DISCUSSION}

Intra-articular glucocorticoid injections for persistent arthritis appeared to be effective albeit temporarily, and significantly decreased the number of steroid hormone receptor positive cells and T cells in ST. None of the baseline ST characteristics predicted the clinical response to glucocorticoid injection. The decrease in ER $\alpha$ positive cells correlated with clinical improvement. The relevance of this correlation and the decrease in the number of steroid hormone receptor positive cells in general need further study.

Previous work on changes in ST in RA showed a marked decrease in synovial macrophages after 2 weeks of oral glucocorticoid therapy ${ }^{32}$ and a decrease in $\mathrm{T}$ cells after intra-articular glucocorticoids. ${ }^{33}$ Despite the greater time span of 12 weeks, the decrease in T cells was confirmed in our study. This probably reflects a long-lasting decrease in proinflammatory activity, possibly enhanced by immobilisation of the joint after injection, and could therefore explain the accompanying clinical effectiveness of the intra-articular glucocorticoid injection, despite previous injections without immobilisation.

The presence of steroid hormone receptor positive cells in ST has been confirmed in several studies. ${ }^{18-21} 23$ The number of positive cells found in this study matches findings in earlier studies. ${ }^{18} 2332$ GRs are thought to be involved in many processes by which increased expression of anti-inflammatory proteins or decreased production of proinflammatory proteins can be achieved. ${ }^{34}$ However, the role of the other steroid hormone receptors is less clear. The effects of intra-articular glucocorticoid injections on the presence of steroid hormone receptor positive cells have not been described before. In this explorative study, we found a decrease in the number of positive cells for all steroid hormone receptors tested. Interestingly, we did not find a correlation between the downregulation of steroid hormone receptor positive cells and the change in $\mathrm{T}$ cells or macrophages. This indicates that the downregulation of steroid hormone receptor positive cells cannot be fully explained by a decrease in proinflammatory cells such as $\mathrm{T}$ cells and macrophages.

Glucocorticoids are thought to work via genomic and nongenomic mechanisms. ${ }^{34}$ Binding of glucocorticoids to their cytosolic receptors initiates the classical genomic pathway and will result in anti-inflammatory effects, which lead to (partial) relief of symptoms and improvement in clinical variables. This is exemplified by the decrease in disability, pain and ESR in this study. Presuming that, similar to the level of ER $\alpha$ messenger RNA, ${ }^{21}$ the level of GR messenger RNA also depends on the degree of inflammation, downregulation of the GR positive cells after glucocorticoid injection may be a logical consequence. Downregulation of positive cells for both ERs and AR is more difficult to understand, but positive correlations between superfusate concentrations of interleukin- 6 and interleukin- 8 and numbers of positive cells for both ERs in ST have been found in patients with RA. ${ }^{18}$ This indicates that inflammatory factors may upregulate the expression of ERs, or vice versa. Androgens are considered to exert anti-inflammatory effects in RA, although therapeutic effects in clinical studies have been limited. ${ }^{13-15} 35$ In this case, downregulation of its receptor may have been caused by downregulation of the inflammatory process as a secondary phenomenon.

Based on our results, the downregulation of $E R \alpha$ positive cells was more pronounced in women and coincided with relief of pain and improvement in joint disability (figure 5), whereas the downregulation of ER $\beta$ positive cells was not significantly associated with clinical response to glucocorticoid injection. The two subtypes of ERs are structurally related, but are encoded by different genes and are thought to mediate different effects. ${ }^{17}$ 
$E R \alpha$ and $E R \beta$ are both present in sensory nerve fibres. ${ }^{36}$ In animal studies, oestrogens increased the expression of substance P precursor ${ }^{37} 38$ and substance $P$ receptors. ${ }^{39}$ Furthermore, $17 \beta$ oestradiol acted directly on the sensory neuron by increasing neurite outgrowth in the absence of other exogenous growth factors. ${ }^{40}$ So, it seems that oestrogens can support neurogenic inflammation and sensitisation to painful stimuli via these mechanisms, and this is in line with the previously described lack of benefit from therapy with oestrogens in RA. ${ }^{16}$ Therefore, a decrease in ER positive cells may lead to a diminished paininducing capacity of oestrogens. The coupling of the downregulation of $E R \alpha$ positive cells and clinical outcome found in this study is certainly another indication of the involvement of ERs in the inflammatory process, as found for the coupling of interleukin- 6 levels and the number of positive cells of both ERs in an earlier study. ${ }^{18}$ However, the underlying mechanisms causing the downregulation of $\mathrm{ER} \alpha$ positive cells are not easily clarified and are probably also partially dependent on the immune stimulus, cell types involved and timing in relation to the disease. ${ }^{17}$ It has been shown that activation of the GR by glucocorticoids induced the expression and activity of oestrogen sulphotransferase, an enzyme important for the metabolic deactivation of oestrogens because sulphonated oestrogens fail to activate the oestrogen receptor. ${ }^{41}$ The inhibition of oestrogen signalling may have caused downregulation of its receptor and the clinical benefit observed.

Our findings are based on data from microscopic analyses of immunohistochemical staining. With this technique, cells are stained for the presence of steroid hormone receptors and are either positive or negative. Of course, the results on cell counts are important in improving our knowledge of the role of these receptors and their link to clinical variables. However, the number of cells does not tell us anything about the amount of receptors within one cell or the effects of glucocorticoids on individual cell populations, and therefore further studies with different techniques would be of additional value.

In our explorative study, we found correlations between the decrease in number of $E R \alpha$ positive cells and clinical variables, but were not able to predict clinical response from pretreatment numbers of steroid hormone positive cells or the number of specific cell populations. The small number of patients in this study and the inclusion of patients with different backgrounds (RA and UA) and with different oral treatments may have influenced the results. Nevertheless, these factors did not appear to influence our exploration of the local effects, which was indicated by the uniform directions of change in receptor positive cells for the RA and UA groups and for the patients with and without oral glucocorticoids. Although results of larger patient groups are often considered more valuable, application of these results at the individual patient level can become less reliable.

In conclusion, we have shown that the number of steroid hormone receptor positive cells are decreased after intra-articular glucocorticoid injection, and the decrease in ER $\alpha$ positive cells correlated with an improvement in clinical outcome, suggesting that steroid hormone receptor positive cells in ST during persistent arthritis play a role in the regulation of inflammation and the response to intra-articular glucocorticoid injection.

Contributors The manuscript has been seen and approved by all authors, who have given necessary attention to ensure the integrity of the work.

Funding This project was financially supported by the Rheumatology Grant 2009 awarded by the Dutch Rheumatology Society (Nederlandse Vereniging voor Reumatologie).

Competing interests None.
Ethics approval Medical ethics committee of UMC Utrecht.

Provenance and peer review Not commissioned; externally peer reviewed.

\section{REFERENCES}

1. Cutolo M, Straub RH, Bijlsma JW. Neuroendocrine-immune interactions in synovitis. Nat Clin Pract Rheumatol 2007;3:627-34.

2. Cutolo $\mathbf{M}$, Straub RH. Insights into endocrine-immunological disturbances in autoimmunity and their impact on treatment. Arthritis Res Ther 2009;11:218.

3. Buttgereit F, Burmester GR, Straub RH, et al. Exogenous and endogenous glucocorticoids in rheumatic diseases. Arthritis Rheum 2011;63:1-9.

4. Gray RG, Tenenbaum J, Gottlieb NL. Local corticosteroid injection treatment in rheumatic disorders. Semin Arthritis Rheum 1981;10:231-54.

5. Habib GS, Saliba W, Nashashibi M. Local effects of intra-articular corticosteroids. Clin Rheumatol 2010;29:347-56.

6. Nelson AM, Conn DL. Series on pharmacology in practice. 9. Glucocorticoids in rheumatic disease. Mayo Clin Proc 1980;55:758-69.

7. Hafström I, Albertsson K, Boonen A, et al. Remission achieved after 2 years treatment with low-dose prednisolone in addition to disease-modifying anti-rheumatic drugs in early rheumatoid arthritis is associated with reduced joint destruction still present after 4 years: an open 2-year continuation study. Ann Rheum Dis 2009;68:508-13.

8. Kirwan JR, Bijlsma JW, Boers M, et al. Effects of glucocorticoids on radiological progression in rheumatoid arthritis. Cochrane Database Syst Rev 2007:CD006356. Jan 24;(1):CD006356"

9. Svensson B, Boonen A, Albertsson K, et al. Low-dose prednisolone in addition to the initial disease-modifying antirheumatic drug in patients with early active rheumatoid arthritis reduces joint destruction and increases the remission rate: a two-year randomized trial. Arthritis Rheum 2005;52:3360-70.

10. van Everdingen AA, Jacobs JW, Siewertsz Van Reesema DR, et al. Low-dose prednisone therapy for patients with early active rheumatoid arthritis: clinical efficacy, disease-modifying properties, and side effects: a randomized, double-blind, placebocontrolled clinical trial. Ann Intern Med 2002;136:1-12.

11. Wassenberg S, Rau R, Steinfeld P, et al. Very low-dose prednisolone in early rheumatoid arthritis retards radiographic progression over two years: a multicenter, double-blind, placebo-controlled trial. Arthritis Rheum 2005;52:3371-80.

12. Bakker MF, Jacobs JW, Welsing PM, et al. Low-dose prednisone inclusion into a methotrexate-based tight control strategy for early rheumatoid arthritis: better control of disease and erosive joint damage. Results from the double-blind randomized CAMERA-II trial. Ann Intern Med 2012;156:329-39.

13. Booji A, Biewenga-Booji CM, Huber-Bruning 0, et al. Androgens as adjuvant treatment in postmenopausal female patients with rheumatoid arthritis. Ann Rheum Dis 1996;55:811-5.

14. Giltay EJ, van Schaardenburg D, Gooren LJ, et al. Effects of dehydroepiandrosterone administration on disease activity in patients with rheumatoid arthritis. $\mathrm{Br} \mathrm{J}$ Rheumatol 1998;37:705-6.

15. Hall GM, Larbre JP, Spector TD, et al. A randomized trial of testosterone therapy in males with rheumatoid arthritis. Br J Rheumatol 1996;35:568-73.

16. van den Brink HR, van Everdingen $A A$, van Wijk MJ, et al. Adjuvant oestrogen therapy does not improve disease activity in postmenopausal patients with rheumatoid arthritis. Ann Rheum Dis 1993;52:862-5.

17. Straub RH. The complex role of estrogens in inflammation. Endocr Rev 2007;28:521-74.

18. Capellino S, Riepl B, Rauch L, et al. Quantitative determination of steroid hormone receptor positive cells in the synovium of patients with rheumatoid arthritis and osteoarthritis: is there a link to inflammation? Ann Rheum Dis 2007;66:53-8.

19. Cutolo M, Accardo S, Villaggio B, et al. Androgen and estrogen receptors are present in primary cultures of human synovial macrophages. J Clin Endocrinol Metab 1996;81:820-7

20. Cutolo M, Accardo S, Villaggio B, et al. Evidence for the presence of androgen receptors in the synovial tissue of rheumatoid arthritis patients and healthy controls. Arthritis Rheum 1992;35:1007-15.

21. Ishizuka M, Hatori M, Suzuki T, et al. Sex steroid receptors in rheumatoid arthritis. Clin Sci 2004;106:293-300.

22. Kim JK, Hann HJ, Kim MJ, et al. The expression of estrogen receptors in the tenosynovium of postmenopausal women with idiopathic carpal tunnel syndrome. J Orthop Res 2010;28:1469-74.

23. Tohyama CT, Yamakawa M, Murasawa A, et al. Localization of human glucocorticoid receptor in rheumatoid synovial tissue of the knee joint. Scand J Rheumatol 2005;34:426-32.

24. van Everdingen AA, Huisman AM, Wenting MJ, et al. Down regulation of glucocorticoid receptors in early-diagnosed rheumatoid arthritis. Clin Exp Rheumatol 2002;20:463-8.

25. Sanden S, Tripmacher R, Weltrich R, et al. Glucocorticoid dose dependent downregulation of glucocorticoid receptors in patients with rheumatic diseases. J Rheumatol 2000;27:1265-70 


\section{Basic and translational research}

26. Huisman AM, Siewertsz van Everdingen AA, Wenting MJ, et al. Glucocorticoid receptor up-regulation in early rheumatoid arthritis treated with low dose prednisone or placebo. Clin Exp Rheumatol 2003;21:217-20.

27. Weitoft T, Larsson A, Rönnblom L. Serum levels of sex steroid hormones and matrix metalloproteinases after intra-articular glucocorticoid treatment in female patients with rheumatoid arthritis. Ann Rheum Dis 2008;67:422-4.

28. Derendorf $\mathbf{H}$, Möllmann H, Grüner $A$, et al. Pharmacokinetics and pharmacodynamics of glucocorticoid suspensions after intra-articular administration. Clin Pharmacol Ther 1986;39:313-7.

29. Chakravarty K, Pharoah PD, Scott DG. A randomized controlled study of postinjection rest following intra-articular steroid therapy for knee synovitis. Br J Rheumatol 1994;33:464-8.

30. Tak PP, van der Lubbe PA, Cauli A, et al. Reduction of synovial inflammation after anti-CD4 monoclonal antibody treatment in early rheumatoid arthritis. Arthritis Rheum 1995:38:1457-65.

31. Kraan MC, Smith MD, Weedon H, et al. Measurement of cytokine and adhesion molecule expression in synovial tissue by digital image analysis. Ann Rheum Dis 2001;60:296-8.

32. Gerlag DM, Haringman JJ, Smeets TJ, et al. Effects of oral prednisolone on biomarkers in synovial tissue and clinical improvement in rheumatoid arthritis. Arthritis Rheum 2004;50:3783-91.

33. af Klint $\mathbf{E}$, Grundtman $\mathrm{C}$, Engström $\mathrm{M}$, et al. Intraarticular glucocorticoid treatment reduces inflammation in synovial cell infiltrations more efficiently than in synovial blood vessels. Arthritis Rheum 2005;52:3880-9.
34. Stahn C, Buttgereit F. Genomic and nongenomic effects of glucocorticoids. Nat Clin Pract Rheumatol 2008;4:525-33.

35. Straub RH, Cutolo M. Involvement of the hypothalamic-pituitary-adrenal/gonadal axis and the peripheral nervous system in rheumatoid arthritis: viewpoint based on a systemic pathogenetic role. Arthritis Rheum 2001;44:493-507.

36. Papka RE, Storey-Workley M, Shughrue PJ, et al. Estrogen receptor-alpha and betaimmunoreactivity and mRNA in neurons of sensory and autonomic ganglia and spinal cord. Cell Tissue Res 2001;304:193-214.

37. Dufourny L, Warembourg M. Estrogen modulation of neuropeptides: somatostatin neurotensin and substance $P$, in the ventrolateral and arcuate nuclei of the female guinea pig. Neurosci Res 1999;33:223-8.

38. Priest CA, Vink KL, Micevych PE. Temporal regulation by estrogen of betapreprotachykinin mRNA expression in the rat ventromedial nucleus of the hypothalamus. Brain Res Mol Brain Res 1995;28:61-71.

39. Pinto FM, Armesto CP, Magraner J, et al. Tachykinin receptor and neutral endopeptidase gene expression in the rat uterus: characterization and regulation in response to ovarian steroid treatment. Endocrinology 1999;140:2526-32.

40. Blacklock AD, Johnson MS, Krizsan-Agbas D, et al. Estrogen increases sensory nociceptor neuritogenesis in vitro by a direct, nerve growth factor-independent mechanism. Eur J Neurosci 2005;21:2320-8.

41. Gong H, Jarzynka MJ, Cole TJ, et al. Glucocorticoids antagonize estrogens by glucocorticoid receptor-mediated activation of estrogen sulfotransferase. Cancer Res 2008;68:7386-93. 


\section{A Intra-articular glucocorticoid injections} decrease the number of steroid hormone receptor positive cells in synovial tissue of patients with persistent knee arthritis

Marlies C van der Goes, Rainer H Straub, Marion J G Wenting, Silvia Capellino, Johannes W G Jacobs, Zalima N Jahangier, Luise Rauch, Johannes W J Bijlsma and Floris P J G Lafeber

Ann Rheum Dis 2012 71: 1552-1558 originally published online April 13, 2012

doi: 10.1136/annrheumdis-2011-201019

Updated information and services can be found at:

http://ard.bmj.com/content/71/9/1552

\section{These include:}

References This article cites 40 articles, 8 of which you can access for free at: http://ard.bmj.com/content/71/9/1552\#BIBL

Email alerting Receive free email alerts when new articles cite this article. Sign up in the service box at the top right corner of the online article.

Collections

Articles on similar topics can be found in the following collections

Degenerative joint disease (4641)

Musculoskeletal syndromes (4951)

Pathology (444)

Clinical diagnostic tests (1282)

Immunology (including allergy) (5144)

Pain (neurology) (883)

Radiology (1113)

Surgical diagnostic tests (431)

\section{Notes}

To request permissions go to:

http://group.bmj.com/group/rights-licensing/permissions

To order reprints go to:

http://journals.bmj.com/cgi/reprintform

To subscribe to BMJ go to:

http://group.bmj.com/subscribe/ 